\title{
Pharmacognostic and Analytical Profile of Leaves of Erythroxylum Moonii Hochr. - An Ethno-Medicinal Plant
}

\author{
Research Article
}

\section{Perera PA N G1*, Acharya Rabinarayan ${ }^{2}$, Pandya P³, Harisha C R ${ }^{3}$, Shukla V J4}

1. P.G. Scholar, 2. Professor and HOD, 3. Laboratory Assistant, Department of Dravyaguna,

4. Head, Pharmacognosy Laboratory, 5. Head, Pharmaceutical Chemistry Laboratory,

ITRA, Jamnagar, Gujarat. India.

\begin{abstract}
Erythroxylum moonii Hochr. is a shrub or small tree in family Erythroxylaceae and folklore claims report the use of its leaves in the treatment of helminthiasis. Aim: Hence, present study aims to evaluate the pharmacognostic and analytical characters including HPTLC of its leaves. Methods: E. moonii fresh and powdered leaves were explored for the macroscopic and microscopic features along with their physico-chemical, phytochemical properties and HPTLC following standard procedures. Results: The leaf of E. moonii is simple, alternate, petiolate, stipulate, elliptic and lanceolate with obtusely caudate-acuminate apex, acute base and entire margins. Fresh leaf is light green, slight astringent with characteristic odour and smooth texture. Powdered dry leaves were light green, slight astringent with aromatic odour and coarse, fibrous texture. Microscopic evaluation revealed the presence of simple, bilobed and stellate trichomes (with and without lignification), rosette, rhomboidal, prismatic and cluster crystals, paracytic stomata and starch grains as key characteristics both in fresh leaves and powdered leaves. Obtained values for loss on drying, total ash, acid insoluble ash, $\mathrm{pH}$, water and methanol soluble extractive were $10.44 \pm 0.31 \%, 2.2 \pm 0.67 \%$, $0.93 \pm 0.06 \%, 5,7.63 \pm 0.57 \%$ and $6.44 \pm 0.38 \%$ respectively. Qualitative phytochemical analysis suggested the presence of carbohydrates, steroids, glycosides, saponins, alkaloids, tannins and flavonoids in the test sample. HPTLC study revealed 17 and 11 peaks at short $(254 \mathrm{~nm})$ and long $(366 \mathrm{~nm})$ ultraviolet consecutively. Conclusion: Obtained results can be used to establish pharmacognostic and analytical standards of leaves of E. moonii which can serve as an important source to determine the quality, purity and strength of the powdered drug.
\end{abstract}

Key Words: Erythroxylum moonii, Pharmacognostical, Physicochemical, Phytochemical, HPTLC, Anthelmintic.

\section{Introduction}

Since centuries people used to treat and manage the diseases with herbal medicine due to their safe nature, wide availability and cost effectiveness. In ancient times, physician himself used to collect the drug hence it was assured about the quality of the raw drug. With the globalization, the demand for herbal medicines were increased and improper substitution as well as harmful adulteration are taking place which create a suspicion on their quality and efficacy. Therefore establishing standards for herbal medicine is an utmost need in order to determine their quality, purity, safety and efficacy and these should be ascertained in a systematic way to gain scientific validation as well as global acceptance for herbal medicine in the system of conventional medicine. $(1,2)$

\section{* Corresponding Author:}

\section{Perera P A N G}

PG Scholar,

Department of Dravyaguna,

IPGT \& RA,

Gujarat Ayurved University, Jamnagar, Gujarat. India.

Email Id: nadigayani@gmail.com
Erythroxylaceae is comprised with 4 genera and about 271 species (3) of shrubs, under shrubs, small and medium sized trees of different ethno-medicinal uses. (4) Generally it is distributed in tropics including South America, Andean region, African tropics and South Asia (Sri Lanka, Southern India). (4) Erythroxylaceae is called as 'coca' family due to its well-known member Erythroxylum coca which is majorly contributed in the extraction of 'cocaine'. 'Cocaine' is a tropane alkaloid that mainly acts as a strong stimulant of central nervous system. Two member plants named Erythroxylum truxilense and Erythroxylum novagranatense are also contributed in the extraction of strong alkaloids like cocaine, hygrine, cinnamylcocaine and truxilline. (4)

Erythroxylum moonii (Fig. 1) being a member of this genus, is claimed to possess a variety of medicinal properties like anthelmintic (5-8), antidysenteric (7, 9), anti-inflammatory (10) and is also used for treating anaemia. $(5,6)$ However, its leaves, which is claimed for above activities have not scientifically studied for its preliminary quality parameters needed by any official herbal pharmacopoeia. Hence, the current study was aimed to study the pharmacognostic, physico-chemical and analytical characters including HPTLC. 


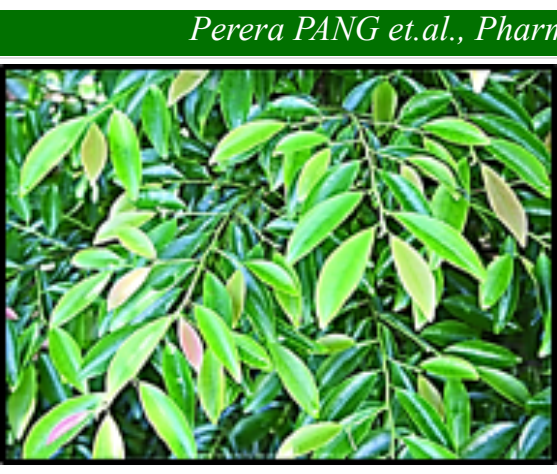

Fig. 1 Whole plant of Erythroxylum moonii Hochr.

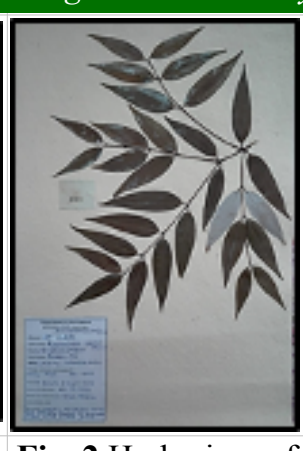

Fig. 2 Herbarium of E. moonii Hochr.

\section{Materials and Methods}

Identification, Collection, Authentication and Preparation of plant material

Leaves of Erythroxylum moonii, after its identification by local herbalist, were collected from Hiniduma, Galle, Sri-Lanka in June 2019 and authenticated by a taxonomist. The name of the plant was conformed with the assistance of https:// indiabiodiversity.org/species/show/11454. (11) Samples of the plant material were preserved both in wet (AAF - 70\% Ethyl alcohol: Glacial acetic acid: Formalin, in the ratio of 90:5:5) and dry (herbarium) condition and kept in the institute museum with the reference number PHM/ 6315/ 20-21 for future reference (Fig. 2). Leaves were cleaned, dried in shade, powdered into a fine powder using 60\# mesh and stored in a tight glass container for further use.

\section{Pharmacognostic study \\ Macroscopic evaluation}

Leaves were appraised visually for its macroscopical features including leaf arrangement, shape, size, apex, base, margin absence or presence of petioles and stipules, venation, mid rib, etc. as per various flora and standard texts. (11-13)

\section{Organoleptic properties}

Organoleptic characters such as colour, odour, taste, touch and texture were assessed in fresh, dry and powdered leaves. (14)

\section{Microscopic examination}

E. moonii leaf observed using thin sections after clearing with chloral hydrate and powdered leaves were also observed for their distinctive characters. (15)

\section{Surface study and Quantitative microscopy}

Surface study of the leaf of E. moonii was carried out to discover the nature and the distribution of stomata, epidermal cells and trichomes.

Under the quantitative microscopy, all micrometric values including size of stomata, stomatal index, individual cells and layers were measured precisely. (16) The study was carried out in triplicate and mean value was expressed in results.

\section{Physicochemical analysis}

Physicochemical parameters such as loss on drying, total ash, acid insoluble ash, $\mathrm{pH}$, water soluble

extractive and methanol soluble extractive were determined as per Ayurvedic Pharmacopeia of India. (17) The experiment was carried out in triplicate and the results were expressed as the mean \pm standard deviation (SD). All used chemicals, solvents and reagents were in analytical grade.

\section{Phytochemical analysis}

Qualitative phytochemical screening was carried out with aqueous and methanol extracts of the leaves of $E$. moonii according to the reported methods $(18,19)$ to investigate the presence of carbohydrates, reducing sugars, proteins, amino acids, steroids, glycosides, saponins, alkaloids, tannins, phenolic compounds and flavonoids.

\section{HPTLC analysis $(20,21)$}

HPTLC was performed by using TLC Aluminium pre coated plate with Silica gel $60 \mathrm{GF}_{254}$ and Toluene: Ethyl acetate (9:1) V/V as mobile phase. Methanolic extract of the powdered leaves of E. moonii applied on plate with the use of Linomat V applicator. Development of the TLC plate was done by Cammag Twin Trough Glass Chamber after saturating with mobile phase for 30 minutes and the development time was 10 mins. The plate was air dried at room temperature after removing from the chamber. Developed plate was scanned with the use of TLC Scanner (Cammag Reprostar III) at the absorption of UV $254 \mathrm{~nm}$ and $366 \mathrm{~nm}$. An integrated software named Wincats 4.02 was used for the detection as well evaluation of data.

\section{Results}

\section{Macroscopic evaluation}

The leaf simple, plano-convex, alternate, elliptic, lanceolate, entire and petiolate with nearly horizontal venation. Surface opaque or dull and shining above and beneath. Apex obtusely caudate-acuminate and base acute. Stipules lanceolate, caducous and present in pairs. Mid rib canaliculated with distinctive nerves above, while having indistinct secondaries and invisible tertiaries. (Fig. 3a)

Quantitative macroscopy revealed that the length and width of the leaf is $3.5-9 \mathrm{~cm}$ and $1.2-2.8$ $\mathrm{cm}$ respectively. Length of the stipule and petiole are $0.3-0.5 \mathrm{~cm}$ and $0.2-0.5 \mathrm{~cm}$ consecutively. (Fig. 3b)

Dried leaf shrunken into its plantar surface by several folds. Venation of the lower surface prominently marked. Shinning in both the surfaces absent.
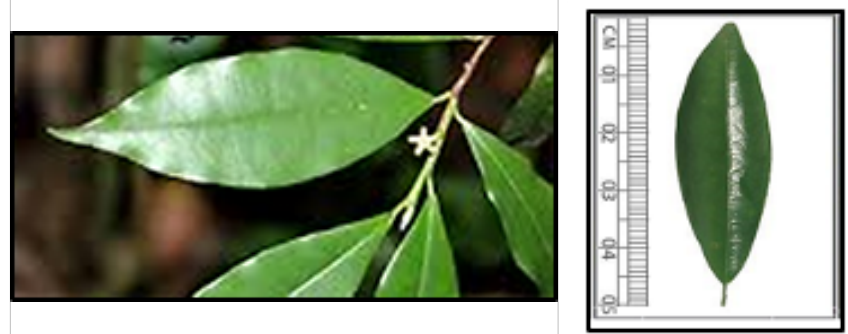

Fig. 3a Macroscopic Features
Fig. 3b Quantitative macroscopy 


\section{Organoleptic properties}

The fresh leaf of E. moonii is light green (light green lower surface and much darker upper surface), slight astringent with characteristic odour and smooth texture.

Upper surface of the shade dried leaf was brownish green and lower surface light green with characteristic odour and slight astringent taste. Lower surface coarse in comparison to the upper surface.

Powdered leaves were light green, slight astringent and sweet in taste with aromatic odour and coarse, fibrous texture.

\section{Microscopic examination Petiole}

It is circular to irregular in shape with epidermis, cortex, vascular bundle and central pith. Epidermis comprised with a single layer of compactly arranged barrel shaped cells. Some epidermal cells are shown with attached simple and bilobed epidermal hairs (trichomes). Cortex is white in colour and parenchymatous. Parenchymal cells loaded with brown content while most are comprising rosette crystals. Several air cavities also are observed in cortical zone. Circular pericyclic fibres with 2-3 celled pocket are followed by endodermis. Circular vascular bundle lead into the pith and pith parenchymal cells are filled with brown content. (Fig. 4a)
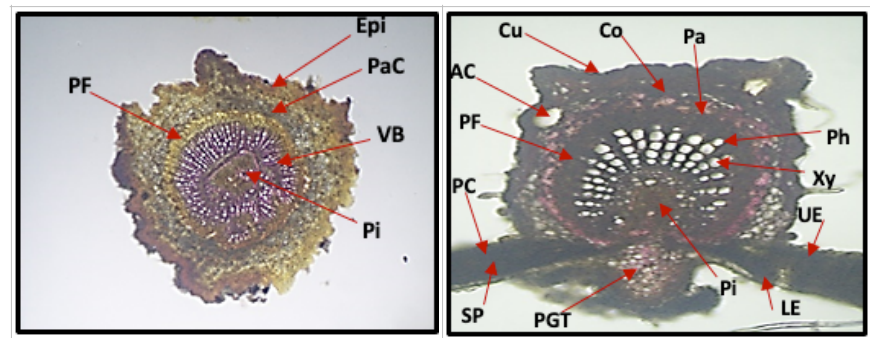

Fig. 4a T.S. of petiole (Epi - Fig. 4b T. S. of leaf through E p i d e r m i s, P a C - mid-rib (AC - Air cavities, Parenchymatous Cortex with $\mathbf{C u}-$ Cuticle, $\mathbf{C o}-$ brown content and rosette Collenchyma, $\mathbf{P a}-$ crystals, VB - Vascular Parenchyma, $\mathbf{P h}-$ Phloem, Bundle, Pi - Pith full of $\mathbf{X y}$-Xylem, UE - Upper parenchymal cells with Epidermis, LE - Lower brown content, PF - Epidermis, Pi - Pith, PGT Pericyclic Fibres) Parenchymatous Ground Tissue, SP - Spongy Parenchyma, PC - Palisade cells, PF - Pericyclic Fibres)

\section{Leaf}

\section{Mid rib}

Dorsi-ventral leaf is distinctive by the character of convex outline of basal region. Single layered epidermis is covered by a thickened cuticle. Epidermal cells are rectangular in shape and some are observed with simple, bilobed and stellate trichomes. Below to the epidermis, several layers of collenchyma is followed by parenchymatous ground tissue and 2-3 air cavities are observed in ground tissue. Circular bundle sheath is covered by pericyclic fibres. Vascular bundle is located in the centre while xylem locating towards upper epidermis and phloem towards lower epidermis. (Fig. 4b)

\section{Lamina}

Lamina of the leaf shows upper and lower epidermis, palisade cells and parenchymal cells. Upper palisade is of two layers and lower spongy parenchyma is of 3-4 layers. (Fig. 4c)

\section{Powder microscopy}

It is observed that the presence of lignified and non-lignified simple and stellate trichomes, rhomboidal, prismatic and cluster crystals, starch grains, fragments of stomata, lignified and non-lignified fibres, annular vessels and fragments of palisade parenchyma in the leaf powder. (Fig. 4d, 4e, 4f, 4g, 4h, and 4i)

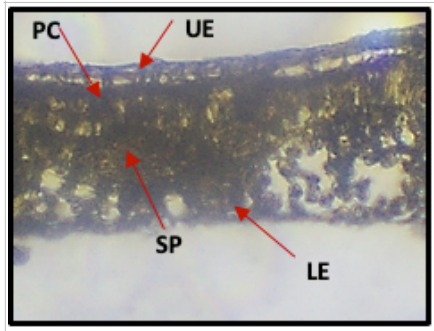

Fig. 4c T.S. of Lamina (UE Upper Epidermis, PC Epidermis, SP - Spongy Parenchyma

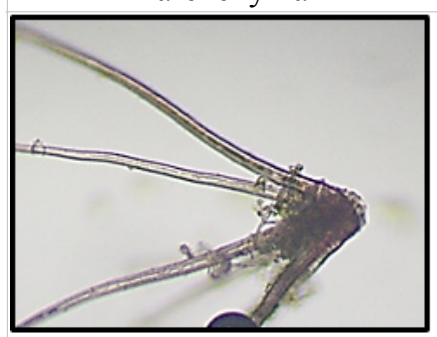

Fig. 4e Lignified stellate trichome

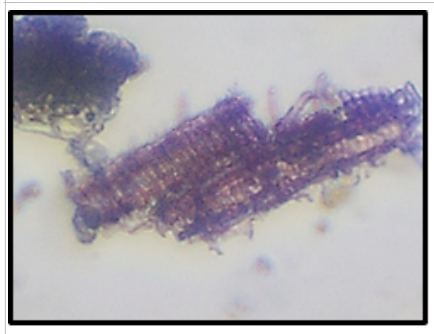

Fig. 4g Fragments of palisade parenchyma
Palisade Cells, LE - Lower

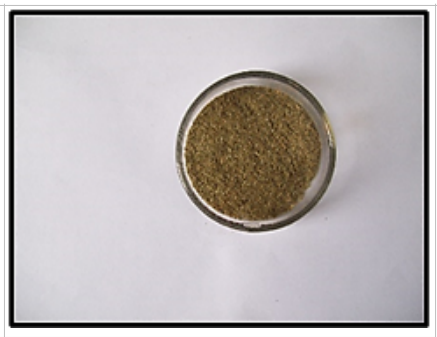

Fig. 4d Powdered leaves of E. moonii

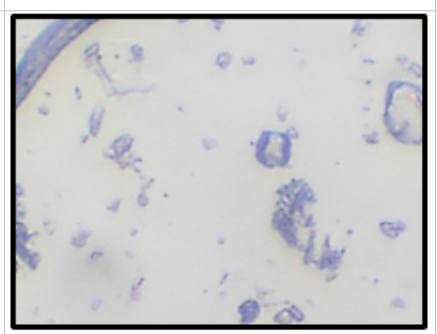

Fig. 4f Prismatic crystals

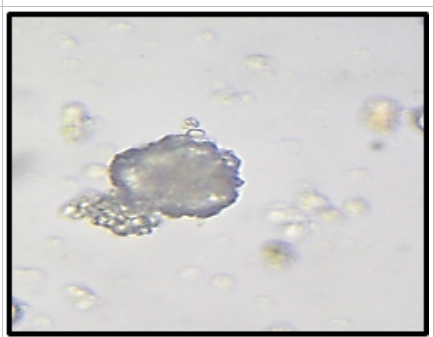

Fig. 4h Cluster crystals

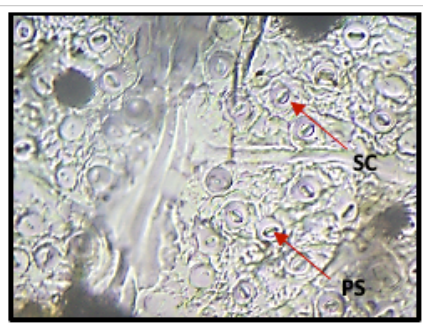

Fig. 4i Paracytic stomata in lower epidermis (PS - Paracytic stomata, SC - Subsidiary Cells) 
Surface study and quantitative microscopy

Surface study revealed the nature and the distribution of stomata and epidermal cells. In lower epidermis, paracytic stomata (Fig. 4i) are observed.

Amount and size of stomata, layers of epidermal cells and stomatal index were determined by quantitative microscopy. (Table 1)

\section{Table 1: Quantitative microscopy of Erythroxylum moonii Hochr. leaf}

\begin{tabular}{|l|l|l|} 
Sr. No. & Parameter & Result \\
\hline 1 & Type of stomata & Paracytic stomata \\
\hline 2 & Length of stomata & $0.4 \mu \mathrm{m}$ \\
\hline 3 & Width of stomata & $0.3 \mu \mathrm{m}$ \\
\hline 4 & Stomatal Index & $33.33 \mathrm{~mm}^{2}$ \\
\hline
\end{tabular}

\section{Physicochemical analysis}

The values of physico-chemical parameters (loss on drying, total ash, acid insoluble ash, water soluble extractive and methanol soluble extractive) of the leaves expressed in percentage are tabulated under Table 2 and it was revealed that leaves of E. moonii are in acidic nature.

Table 2: Values of physicochemical parameters of the leaves of $E$. moonii Hochr.

\begin{tabular}{|c|l|c}
\hline Sr. No. & \multicolumn{1}{|c|}{ Physicochemical parameter } & Value \\
\hline a) & Loss on drying at $110^{\circ} \mathrm{C}(\% \mathrm{w} / \mathrm{w})$ & $10.44 \pm 0.31$ \\
\hline b) & Ash value $(\% \mathrm{w} / \mathrm{w})$ & $2.2 \pm 0.67$ \\
\hline c) & Acid insoluble ash $(\% \mathrm{w} / \mathrm{w})$ & $0.93 \pm 0.06$ \\
\hline d) & Water soluble extractive $(\% \mathrm{w} / \mathrm{w})$ & $7.63 \pm 0.57$ \\
\hline e) & Methanol soluble extractive $(\% \mathrm{w} / \mathrm{w})$ & $6.44 \pm 0.38$ \\
\hline f) & $\mathrm{pH}$ & 5 \\
\hline
\end{tabular}

\section{Phytochemical analysis}

Obtained results for preliminary phytochemical screening of aqueous and methanol extracts of the leaves are shown in Table 3.

Table 3: Phytochemical analysis of the leaves of $E$. moonii Hochr.

Sr. Name of the

No. constituent

Test performed Presence/ absence of the substance

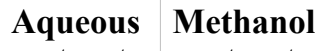
extract extract
a) Carbohydrates Molisch's test
b) Reducing sugars Fehling's test
c) Proteins Biuret test
d) Amino acid Ninhydrin test
e) Steroids
f) Glycosides
Salkowski reaction Keller-
g) Saponins
h) Alkaloids
Tannins \&
i) phenolic
j) Flavonoids
Killiani test
Foam test
Dragendorff's

$+\quad+$
Lead acetate solution test
Lead acetate solution test ['+'= Present, '-' = Absent $]$

\section{HPTLC}

Methanolic extract of powdered leaves of $E$. moonii was evaluated for HTPLC. It was scanned under $254 \mathrm{~nm}$ and $366 \mathrm{~nm}$ and obtained $\mathrm{R}_{\mathrm{f}}$ values are mentioned in Table 4.

Table 4: Obtained $R_{\mathrm{f}}$ values for the leaves of $E$. moonii under the wave lengths of $254 \mathrm{~nm}$ (short) \& $366 \mathrm{~nm}$ (long)

\begin{tabular}{|c|c|c|}
\hline $\begin{array}{c}\text { Number of } \\
\text { peaks } \\
\text { obtained }\end{array}$ & $\begin{array}{c}\mathbf{R}_{\mathbf{f}} \text { Values } \\
\text { Under UV 254nm }\end{array}$ & $\begin{array}{c}\text { Under UV } \\
\mathbf{3 6 6 n m}\end{array}$ \\
\hline 1 & 0.04 & 0.07 \\
\hline 2 & 0.08 & 0.17 \\
\hline 3 & 0.23 & 0.24 \\
\hline 4 & 0.24 & 0.33 \\
\hline 5 & 0.29 & 0.41 \\
\hline 6 & 0.35 & 0.44 \\
\hline 7 & 0.44 & 0.50 \\
\hline 8 & 0.50 & 0.69 \\
\hline 9 & 0.57 & 0.71 \\
\hline 10 & 0.61 & 0.72 \\
\hline 11 & 0.63 & 0.74 \\
\hline 12 & 0.66 & \\
\hline 13 & 0.67 & \\
\hline 14 & 0.69 & \\
\hline 15 & 0.70 & \\
\hline 16 & 0.72 & \\
\hline 17 & 0.74 & \\
\hline
\end{tabular}

It shows 17 peaks under the wave length of $254 \mathrm{~nm}$ and 11 peaks under $366 \mathrm{~nm}$. Six similar spectra is revealed at $0.24 \mathrm{R}_{\mathrm{f}}, 0.44 \mathrm{R}_{\mathrm{f}}, 0.50 \mathrm{R}_{\mathrm{f}}, 0.69 \mathrm{R}_{\mathrm{f}}, 0.72 \mathrm{R}_{\mathrm{f}}$ and $0.74 \mathrm{R}_{\mathrm{f}}$. Peak display and spectral comparison are shown in Fig. 5a, 5b and 5c respectively.

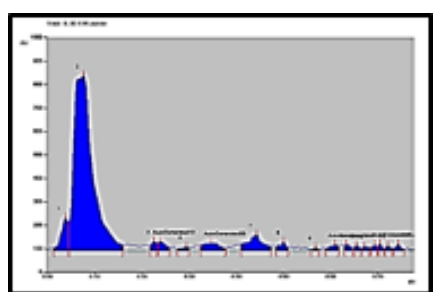

Fig. 5a Densitogram of leaf Fig. 5b Densitogram of leaf at $254 \mathrm{~nm}$

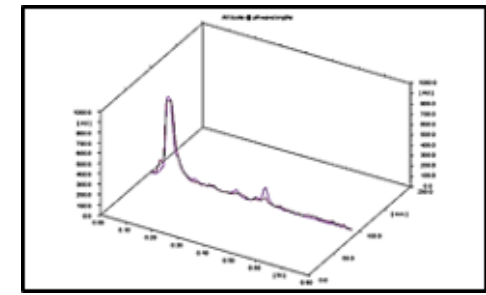

Fig. 5c Comparative spectra at $254 \mathrm{~nm}$ and 366nm

\section{Discussion}

Present study reports the pharmacognostic, physicochemical and HPTLC of the leaves of E. moonii for the first time. Macroscopically and organoleptically it was observed that the presence of several distinct features of fresh and powdered leaves in between the 
species of the genus of Erythroxylum that can be used as diagnostic characteristics. $(22,23)$ Both macroscopic and organoleptic characters may closely resembled by other substitutes and adulterants due to their subjective nature. Hence it is crucial to validate the plant materials and the crude drug microscopically as well as physicochemically in the purpose of identification and authentication. $(24,25)$

The shape of epidermal cells of a leaf is helpful in solving taxonomic problems (26-29) and stomatal characteristics are vital in the identification of plant. $(30,31)$ Presence of rectangular shaped epidermal cells and huge number of paracytic stomata in the lower epidermis may help in the identification of the leaves. Epidermal hairs otherwise called as trichomes are also recognized as taxonomic markers in relation to the identification of plant species. (32-34) Several lignified and non-lignified simple and stellate trichomes were observed in upper epidermis of the leaf which can be identified as taxonomic markers. Oliveira et al (2012) reported that anatomical and histochemical characterization of vegetative parts of medicinal plants is important. (35) In the current study, leaf anatomy revealed certain diagnostic features like different types of calcium oxalate crystals (rhomboidal, prismatic, rosette and cluster crystals), starch grains, vascular bundle with circular pericycle, upper palisade parenchyma and lower spongy parenchyma that may provide an idea of the regions in which chemical reactions are taken place. The micro structures like starch granules and all the crystals of calcium oxalate have diagnostic value in the proper identification of unorganized crude drugs. (36) Further it can be stated that crystals of calcium oxalate play a vital role in plant defense mechanism (37) also.

Malati et al (2005) reported that powder microscopy is also an important method in identifying plant species and authentifying the crude drug. (38) In the study, leaf powder was found with the presence of cluster, rhomboidal and prismatic crystals, lignified and non-lignified simple and stellate trichomes, starch grains, fragments of palisade parenchyma, annular vessels and fragments of paracytic stomata which may assist the identification of plant species and authenticating the crude drug.

Assessment of physicochemical parameters is needed in establishing the standards for the crude drug and in the detection of adulterants. (39) The obtained value of loss on drying is $10.44 \pm 0.31 \% \mathrm{w} / \mathrm{w}$, indicates an efficient process of drying that provide the stability to the powdered leaves during storage. It also implies the retention of phyto constituents for a long time. So that, having less water activity, powdered leaves of $E$. moonii may less susceptible to the microbial spoilage and enzymatic activity that causing degradation of the quality attributes as well as phyto constituents. (40)

Obtained values for total ash and acid insoluble ash are $2.2 \pm 0.67 \% \mathrm{w} / \mathrm{w}$ and $0.93 \pm 0.06 \% \mathrm{w} / \mathrm{w}$ respectively. Total ash may include both physiological ash derived from plant material itself and nonphysiological ash consist of sand and siliceous earth. Physiological ash may comprise mineral nutrients also.
Non-physiological ash is resembled by acid insoluble ash. The difference between total ash and acid insoluble ash indicates the organic material content of the powdered leaves.

Extractive values depict the purity of the material hence adulterated drugs can be easily identified. These may provide the knowledge of suitable solvents in extraction and assist in the evaluation of nature and amount of solutes in powdered plant material. (41, 42) The constituents of leaves of Erythroxylum moonii were soluble in both methanol $(6.44 \pm 0.38 \% \mathrm{w} / \mathrm{w})$ and water $(7.63 \pm 0.57 \% \mathrm{w} / \mathrm{w})$ with higher solubility in methanol. It implies the presence of more water soluble contents like acids, gum and inorganic compounds rather than methanol soluble contents such as alkaloids, flavonoids, steroids. $(41,42)$ $\mathrm{pH}$ value (5) shows the acidic nature of the crude drug.

It has been reported that the leaves of E. moonii are absent with starch, glycosides and alkaloids. [43] However, it was not observed in the present analysis, in both water and methanol extracts. It could be due to several factors such as geographical differences, soil type, collection time, phenological growth, etc. Although several alkaloids were found pertaining to the studies on plant of E. moonii, actions of them have not been revealed yet. $(44,45)$ However contained phyto constituents, provide the idea of applicability of the plant material in variety of pharmacological activities. According to the reported details, these phyto constituents possess antioxidant, anticancer, antitumor, hepatoprotective, anti-inflammatory, hypoglycemic, antiviral, antibacterial, and antifungal activities. (46)

It was discovered that Toluene: Ethyl Acetate $(9: 1 \mathrm{v} / \mathrm{v})$ is the most suitable solvent system for HPTLC of methanol extract of powdered E. moonii leaves. In spectral comparison six similar spectra were found at $0.24 \mathrm{Rf}, 0.44 \mathrm{Rf}, 0.50 \mathrm{Rf}, 0.69 \mathrm{Rf}, 0.72 \mathrm{Rf}$ and $0.74 \mathrm{Rf}$ among the 17 peaks at $254 \mathrm{~nm}$ and 11 peaks at $366 \mathrm{~nm}$. Similar studies have been carried out for other genera to determine the chemical composition as well as the identity of the plant materials. (47) Hence, these values can be used in the identification of the plant and in determination of chemical composition in future studies.

\section{Conclusion}

The obtained result of the Pharmacognostic, physicochemical, phytochemical and HPTLC may be taken as the main vital diagnostic characteristics of the leaves of Erythroxylum moonii Hochr. for the identification and authentication of the crude drug (powder). These parameters can be used as reference standards of the powdered leaves in the preparation and maintaining the quality, purity and strength of the crude drug. They may also assist the preparation process of official monograph for the plant.

\section{Acknowledgement}

The authors are thankful to Director, ITRA, Jamnagar, India for funding and providing facilities to carry out the research work and also thankful to Dr. Switu Jani and Dr. Sudipta Roy (SRF, Anukta Dravya Project) for their technical assistance during the experiment. 


\section{Competing interest}

Authors have declared that no competing interests exist.

\section{References}

1. Fiaz A, Qazi NS. Pharmacognostic standardization and preliminary phytochemical studies of Gaultheria trichophylla. Pharmaceutical Biology. 2015; 53(12): 1-8.

2. Pan SY, Zhou SF, Gao SH, Yu ZL, Zhang SF, Tang $\mathrm{MK}$, et al. New perspectives on how to discover drugs from herbal medicines: CAM'S outstanding contribution to modern therapeutics. Evidence Based Complementary Alternative Medicine. 2013; 627-735.

3. Christenhusz MJM, Byng JW. The number of known plants species in the world and its annual increase. Phytotaxa. 2016; 261 (3): 201-217.

4. https://www.sciencedirect.com/topics/biochemistrygenetics-and-molecular-biology/erythroxylaceae dated 19-07-2020

5. Compendium of Medicinal Plants A Sri Lankan Study. $1^{\text {st }}$ ed. Vol 4. Colombo: Department of Ayurveda; 2004. p.138-141.

6. Osuturu Visituru. Vol 4. Colombo: Department of Ayurveda; 1994. p.131.

7. http://www.instituteofayurveda.org/plants/ plants_detail.php?i=472\&s=Local_name dated 20-07-2020

8. Nambiar VPK, Sasidharan N, Renuka C, Balagopalan M. Studies on the Medicinal Plants of Kerala Forests. Thrissur: Kerala Forest Research Institute; 1985. p.21.

9. https://biodiversityofsrilanka.blogspot.com/ 2017/05/bata-kirilla-erythroxylum-moonii.html dated 19-07-2020

10. Jayaweera DMA. Medicinal Plants (Indigenous and Exotic) Used in Ceylon. Colombo: National Science Council; 1980. p.187-188.

11. Sharma OP. Plant taxonomy. $2^{\text {nd }}$ ed. New Delhi: Tata Mc Graw-Hill education private limited; 2009. p.29-34, 440-457.

12. https://indiabiodiversity.org/species/show/11454 dated 17-07-2020

13. Hooker JD, CB. The Flora of British India. Vol 1. London: L. Reeve \& Co; 1872. p.415.

14. Trease and Evanes. Pharmacognosy. 16 th ed. London: Saunders Elsevier publication; 2009. p.521-547.

15. Khandelwal KR. Practical Pharmacognosy techniques and experiments. 19th ed. Pune: Nirali Prakashan; 2008. p.26-27.

16. Trease and Evanes. Pharmacognosy. 16th ed. London: Saunders Elsevier publication; 2009. p.569-570.

17. Anonymous. The Ayurvedic Pharmacopoeia of India. 1st ed. Part-II. Vol-II. New Delhi: Department of AYUSH, Ministry of Health and Family Welfare; 2008.

18. Kasture AV, Mahadik KR, More HN, Wadodkar SG. Pharmaceutical analysis. $18^{\text {th }}$ ed. Vol 2. Nirali Prakashan; 2009.
19. Baxi AJ, Shukla VJ, Bhat UB. Methods of qualitative testing of some Ayurvedic formulations. Jamnagar: Gujarat Ayurved University; 2001. p. $5-12$.

20. https://www.slideshare.net/MaheshPratapwar1/ hptlc-70376776?next_slideshow $=1$ dated 17-08-2020

21. Pawar RK, Sharma S, Singh KC, Sharma RKR. Development and validation of HPTLC method for the determination of catechin from Smilax Perfoliata Lour Root. Int J Curr Pharm Res. 2011; 3(1): 30-34.

22. Gamble JS. Flora of the Presidency of Madras. Vol 1. Dehradun: Shiva Offset press; 2011. p.127.

23. Kirtikar KR, Basu BD, ICS. Indian Medicinal Plants. $2^{\text {nd }}$ ed. Vol 1. Bishen Singh Mahendrapal Singh; 1935.

24. Ajaykumar RS, Rajendra DW. Pharmacognostic study and development of quality parameters of Hamelia patens jacq. Stems. Der Pharmacia Lettre. 2016; 8(8): 6-13.

25. Kumar D, Pravin PV, Zulfikar AB, Jeevan D, Yogesh K, Santosh B. Macroscopical and microscopical evaluation of leaves of Clerodendrum inerme Gaertn. International Journal of Biological \& Medical Research. 2011; 2(1): 404-408.

26. Banerjee A, Rahaman $\mathrm{CH}$, Kar RK, Mandal S. Micromorphology of foliar epidermis of some tropical tree legumes. Phytomorph. 2002; 52(2-3): 223-230.

27. Ogundipe OT, Akinrinlade O. Epidermal micromorphology of some species of Albizia durazz (Mimosaceae). Phytomorph. 1998; 48: 325-333.

28. Pal K, Rahaman $\mathrm{CH}$. Studies on foliar epidermal micromorphology, vegetative anatomy and xylem elements of four members of Protulacaceae. Int $\mathrm{J}$ Cur Res. 2014; 6(2): 4968-4975.

29. Parveen NS, Murthy KSR, Pullaiah T. Leaf epidermal characters in Crotalaria sp. (Papilionoideae) from Eastern Ghats. Phytomorph. 2000; 50: 205-212.

30. Inamdar JA. Epidermal structure and ontogeny of caryophyllaceous stomata in some Acanthaceae. Bot Gaz. 1970; 131: 261-268.

31. Kothari MJ, Shah GL. Epidermal structure and ontogeny of stomata in the Papilionaceae. Bot Gaz. 1975; 136: 372-379.

32. Leelavathi PM, Ramayya N. Structure, distribution and classification of plant trichomes in relation to taxonomy II. Caesalpinioidae. Ind. J For. 1983; 6: 43-56.

33. Mukherjee KK, Roy M, Saha PK, Ganguly SN. Surface morphology of tea. (Camellia sinensis L.) leaves. Phytomorph. 2000; 50:125-131.

34. Rao RS, Ramayya N. Trichome types and their taxonomic importance in the Tiliaceae. Ind $\mathrm{J}$ Bot. 1987; 10: 65-73.

35. D'Oliveira AB, D'Mendonsa MS, Azevedo AA, Meira RMSA. Anatomy and histochemistry of the vegetative organs of Cissus verticillata - a native 
medicinal plant of the Brazilian Amazon. Brazilian Journal of Pharmacognosy. 2012; 22(6):1201-1211.

36. Jackson BP, Snowdow. Powdered Vegetable DrugsAn Atlas of Microscopy for use in the Identification and Authentication of some Plant Materials employed as Medicinal Agents. London: J. \& A Churchill Ltd; 1968.

37. Franceschi VR, Nakata PA. Calcium oxalate in plants: formation and function. Annu Rev Plant Biol. 2005; 56: 41-71.

38. Malati G, Pillai APG. Microscopic profile of powdered drugs used in Indian systems of medicine; Volume 2: Leaf drugs. Jamnagar: Institute of Ayurvedic Medicinal Plant Sciences;2005.

39. Anonymous, Indian pharmacopoeia 3(2). New Delhi: Controller of Publications, Ministry of Health and Family Welfare; 1985.

40. Pandey MK, Singh, GN, Sharma, RK, Lata S. Standardization of yakritplihantak churna. An ayurvedic poly herbal formulation. International Journal of Pharmaceutical Sciences Research. 2012; 3:171-176.

41. Shwetajain SC, Khatri P, Jain A, Vaidya A. Pharmacognostic and phyto chemical investigations of the leaves of Zizyphus xylopyrus (Retz) willd. International Journal of Pharmacy and Pharmaceutical Sciences. 2011; 3:122-125.
42. Kripa KG, Sangeetha R, Chamundeeswari D. Pharmacognostical and physicochemical evaluation of the plant Leucas aspera. Asian Journal of Pharmaceutical and Clinical Research. 2016; 9:263-268.

43. Kindo I, Britto SJ, Arulappan MT, George M. Phytochemical Evaluation of the Ethanolic and Aqueous Leaf Extracts of Erythroxylum moonii (Hochr), Henckelia humboldtiana (Gardner) A.Weber \& Burtt and Cipadessa baccifera (Roth) Miq. International Journal of Innovative Drug Discovery. 2014; 4(3): 145-147.

44. Rahman AU, Khattak KF, Nighat F, Shabbir M, Hemalal KD, Tillekeratne LM. Dimeric tropane alkaloids from Erythroxylum moonii. Phytochemistry. 1998; 48(2): 377-383.

45. Khattak KF, Rahman AU, Choudhary MI, Hemalal KD, Tillekeratne LM. New tropane alkaloids from Erythroxylum moonii. J. Nat. Prod. 2002; 65: 929 931.

46. Kytidou K, Artola M, Overkleeft HS, Aerts JMFG. Plant Glycosides and Glycosidases: A TreasureTrove for Therapeutics. Frontiers in Plant Science. 2020; 11:1-21.

47. Pawar RK, Sharma S, Singh KC, Sharma Rajeev KR. Development and Validation of HPTLC Method for the Determination of catechin from Smilax perfoliata Lour Root. Int J Curr Pharm Res. 2011; 3(1): 3034. 